\title{
Chrome-calcium, Magnesium-number and Yttrium characteristics of garnets in depleted Lherzolitic, Harzburgitic and Dunitic mantles
}

Grütter, H. S.

Anglo American Research Laboratory, P. O. Box 106, Crown Mines, 2025, South Africa.

Garnets that occur in mantle peridotites are particularly useful to earth scientists because their $\mathrm{Cr}_{2} \mathrm{O}_{3}-\mathrm{CaO}$ chemistries monitor the presence or absence of coexisting pyroxenes (Sobolev et al., 1973 ) and reflect P-T conditions when spinel-saturated (Malinovsky and Doroshev, 1977). Their resistant nature and diamond-associated subcalcic chemistry (Gurney and Switzer, 1973) has ensured extensive use of garnet $\mathrm{Cr}_{2} \mathrm{O}_{3}-\mathrm{CaO}$ chemistry in exploration for primary diamond deposits. The observation that garnet chemistry reflects P-T-X conditions so sensitively may be attributed to the unique character and wide P-T stability of garnet solid solutions which are thus well placed to exploit the bulk compositional variability that exists for $\mathrm{CaO}, \mathrm{Cr}_{2} \mathrm{O}_{3} / \mathrm{Al}_{2} \mathrm{O}_{3}, \mathrm{MgO} / \mathrm{FeO}$ and $\mathrm{TiO}_{2}$ in peridotites. Since these elements and ratios are significantly affected by melt-depletion (and meltmetasomatism), it follows that garnet chemistries may be used as tracers of such processes.

Inspection of $\mathrm{Cr}_{2} \mathrm{O}_{3}-\mathrm{CaO}$ plots representing $>10^{6}$ peridotitic garnet xenocrysts derived from worldwide kimberlites, lamproites and related rocks shows that three basic types of residual mantle chemistries may be generated by melt-depletion processes which act on a (conceptual) starting garnet composition of $\sim 1 \% \mathrm{Cr}_{2} \mathrm{O}_{3}, 5 \% \mathrm{CaO}$ as found in fertile peridotite:

- Lherzolitic (L-type) mantles contain no, or very few, subcalcic garnets. Their garnet chemistries can reach very high $\mathrm{Cr}_{2} \mathrm{O}_{3}$ contents (up to 16 or $18 \% \mathrm{Cr}_{2} \mathrm{O}_{3}$ ), but are constrained to increasing $\mathrm{CaO}$ values by clinopyroxene saturation (Fig. 1a). The observation that these mantles have not encountered "cpx-out" during melting indicates that they have experienced less than 20 to $25 \%$ melt extraction (Takahashi et al., 1993).

- Harzburgitic (H-type) mantles have low to very high $\mathrm{Cr}_{2} \mathrm{O}_{3}$ garnets similar to those of L-type mantles, but typically contain up to $\sim 20 \%$ subcalcic garnets which, however, do not have $\mathrm{CaO}$ $<1.8 \%$ (Fig. 1b). Examples from the Shandong, Mali, Botswana, Kuruman and Mbuji-Mayi kimberlite provinces indicate that garnet chemistries are constrained to $\mathrm{Cr}_{2} \mathrm{O}_{3}<11 * \mathrm{CaO}-14.6$ (roughly $\mathrm{CaO}>1.8 \%$ ), and it is tempting to insert a notional "opx-out" divide at $\mathrm{CaO}=1.8 \%$. The notion arises from the refractory nature and high modal olivine contents reported for megacrystalline dunite xenoliths from Siberia (Pokhilenko et al., 1991), but in detail it is inconsistent with the presence of modal orthopyroxene in many harzburgite xenoliths that contain garnets with $\mathrm{CaO}<1.8 \mathrm{wt} \%$. The $\sim 1.8 \mathrm{wt} \% \mathrm{CaO}$ divide is however very close to "high-sodium cpx-out" in garnet peridotites as defined by Sobolev et al. (1973), suggesting that it may well form a distinctive petrologic divide.

- Dunitic (D-type) mantles are typified by abundant subcalcic garnets, locally forming up to $40 \%$ of the garnet concentrate. Examples from the Kimberley area, Udachnaya and the central Slave kimberlite provinces have the distinctive characteristics that $\mathrm{Cr}_{2} \mathrm{O}_{3}$ rarely exceeds $13 \mathrm{wt} \%$ for lherzolitic or subcalcic grains, while the subcalcic grains cross the $\sim 1.8 \% \mathrm{CaO}$ divide to much lower $\mathrm{CaO}$ values (Fig. 1c). Such $\mathrm{CaO}$-poor garnets most likely represent extremely refractory dunite xenolith bulk compositions which can be generated from fertile peridotite by $>50 \%$ melt extraction (e.g. Fig. 1 in Pearson et al., 1995). 
Figure $1 \mathrm{~d}$ is a schematic summary of the melt-depletion arrays that give rise to L-, $\mathrm{H}$ - and D-type mantle chemistries. It is noted that progressive depletion is characterised by increased $\mathrm{Cr}_{2} \mathrm{O}_{3}$, followed by decreased $\mathrm{CaO}$, such that the angle $\mathrm{TAN}^{-1}\left(\mathrm{Cr}_{2} \mathrm{O}_{3} / \mathrm{CaO}\right)$ may be used as a measure of the extent of depletion. A variety of garnet major- and trace-element parameters for concentrate garnets from kimberlites that straddle the southwestern Kaapvaal craton boundary are plotted against this measure of depletion in Fig. 2, from which stem the following observations:

- Garnet Mg-numbers $(=\mathrm{Mg} /[\mathrm{Mg}+\mathrm{Fe}])$ increase with $\mathrm{ATAN}\left(\mathrm{Cr}_{2} \mathrm{O}_{3} / \mathrm{CaO}\right)$ at a slope that is significantly steeper than calculated for $\mathrm{Ca}-\mathrm{Mg}$-Fe crystal chemical effects at constant $\mathrm{P}, \mathrm{T}$ and olivine forsterite contents (using O'Neill and Wood, 1979). The garnet Mg-numbers thus record depletion events (which are equivalent to changes in olivine composition of Fo90 to Fo95).

- FeO in garnet is a mirror image of the Mg-number trend, as expected (not illustrated).

- Yttrium in garnet reflects melt-depletion quite sensitively, but occasionally shows values indicative of melt-metasomatic interaction ( $\mathrm{Y}>30 \mathrm{ppm}$ ). Melt-metasomatic overprint trends are also seen in plots of $\mathrm{TiO}_{2}, \mathrm{Ti} / \mathrm{Y}, \mathrm{Y} / \mathrm{Ga}$ or $\mathrm{Zr} / \mathrm{Y}$ vs. ATAN $\left(\mathrm{Cr}_{2} \mathrm{O}_{3} / \mathrm{CaO}\right)$ and care is needed in interpreting melt-depletion trends from the resultant data (not illustrated).

In conclusion, it is noted that three basic types of melt-depletion arrays may be defined with relative ease on $\mathrm{Cr}_{2} \mathrm{O}_{3}-\mathrm{CaO}$ plots for peridotitic garnets (Fig. 1). It is tempting to correlate the extremely depleted arrays represented by D- and H-type mantles with severe melt-depletion events in the Archaean, and conversely, to assign Proterozoic or younger ages to the less severe melt-depletion arrays typical of L-type mantles (e.g. Griffin et al., 1997). Such correlations appear to be substantiated by garnet $\mathrm{Cr}_{2} \mathrm{O}_{3}-\mathrm{CaO}$ arrays on average, but in detail, fail to predict the presence of $\mathrm{L}$ type mantles underlying large tracts of Archaean continental crust. It hence appears that not all Archaean subcontinental lithosphere has experienced extensive melt-depletion. The processe(s) that give rise to extreme melt extraction are therefore likely to have provincial or tectonic dimensions in addition to the temporal aspects already identified by Griffin et al. (1997).

\section{References}

Griffin, W. L., O' Reilly, S. Y., Ryan, C. G., Gaul, O. and Ionov, D. A., 1997, Secular variation in the composition of subcontinental lithospheric mantle: Geophysical and geodynamic implications. Amer. Geophys. Union Monogr., in press.

Gurney, J. J. and Switzer, G. S., 1973, The discovery of garnets closely related to diamonds in the Finsch pipe, South Africa: Contr. Mineral. Petrol., 39, 103-116.

Malinovsky, I. Y. and Doroshev, A. M., 1977, Evaluation of P-T conditions of diamond formation with reference to chrome-bearing garnet stability: Ext. Abs. 2IKC, Santa Fe, no page numbers.

O'Neill, H. St. C. and Wood, B. J., 1979, An experimental study of Fe-Mg partitioning between garnet and olivine and its calibration as a geothermometer: Contr. Mineral. Petrol., 70, 59-70.

Pearson, D. G., Carlson, R. W., Shirey, S. B., Boyd, F. R. and Nixon, P. H., 1995, Stabilisation of Archaean lithospheric mantle: A Re-Os isotope study of peridotite xenoliths from the Kaapvaal craton: Earth Planet. Sci. Lett., 134, 341-357.

Pokhilenko, N. P., Pearson, D. G., Boyd, F. R. and Sobolev, N. V., 1991, Megacrystalline dunites and peridotites: hosts for Siberian diamonds, Ann. Rep. Dir. Carn. Inst. Wash. 1991, 11-18.

Sobolev, N. V., Lavrent'ev, Y. G., Pokhilenko, N. P. and Usova, L. V., 1973, chrome-rich garnets from the kimberlites of Yakutia and their parageneses: Contr. Mineral. Petrol., 40, 39-52.

Takahashi, E., Shimazaki, T., Tsuzaki, Y. and Yoshida, H., 1993, Melting study of a peridotite KLB-1 to $6.5 \mathrm{GPa}$, and the origin of basaltic magmas: Phil. Trans. R. Soc. Lond. A342, 105-120. 

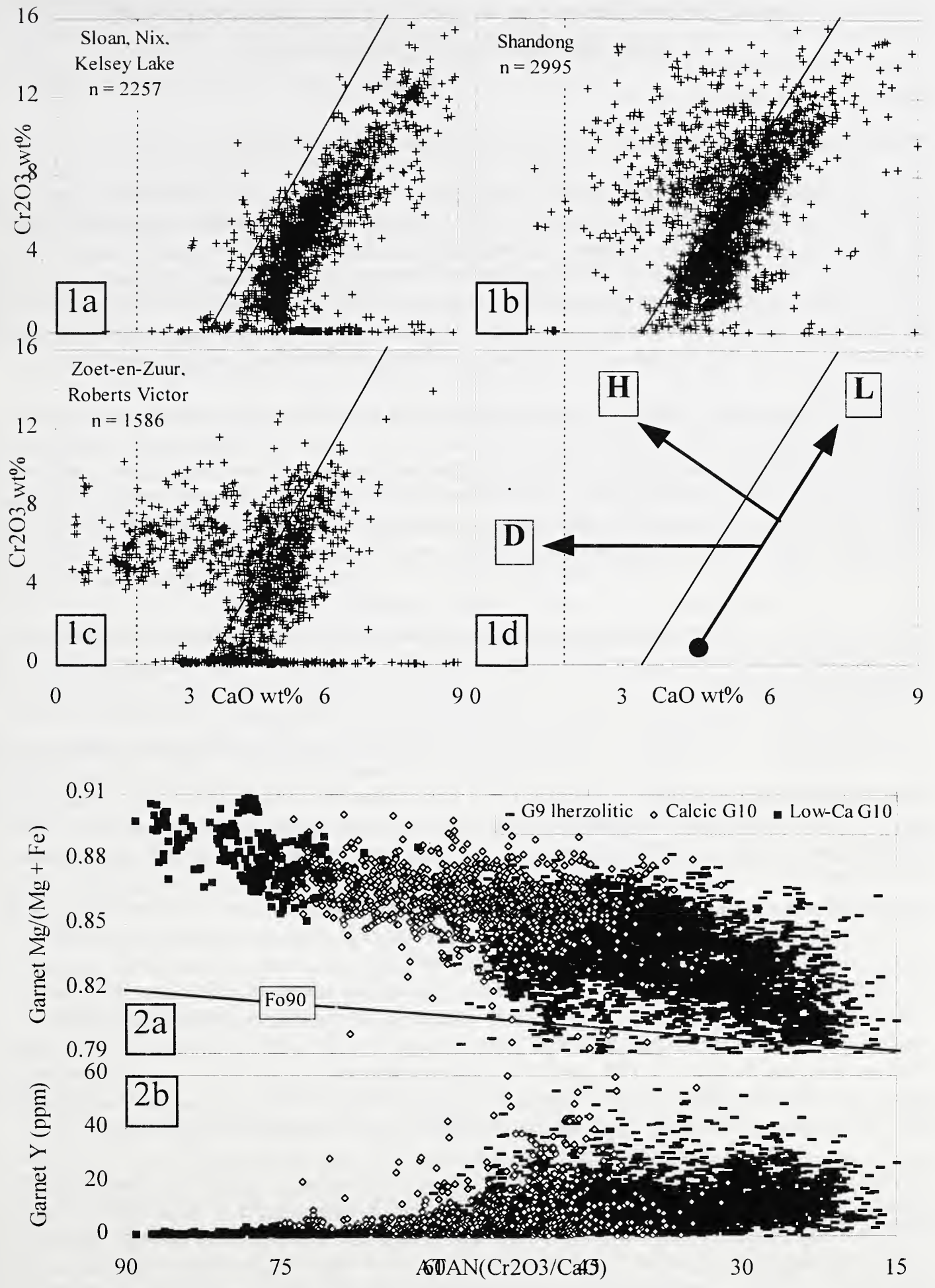